\title{
Corporate Governance System and Quality of Financial Information
}

\author{
Jouini Fathi \\ Faculty of economic and management of Sousse, Tunisia \\ fathijouini@fdseps.rnu.tn
}

\section{Doi:10.5901/mjss.2013.v4n2p129}

\begin{abstract}
:
At this study, we try to find the relationship between the system of governance and the quality of financial information for a sample of French companies listed in the SBF 250 for a period from 2004 to 2008. The Quality of financial information is approximated by discretionary accruals. Corporate governance is appreciated by a global index with 64 items and three sub-indices relating to the characteristics of the board, ownership structure and quality of the control system. Our results demonstrate that the quality of financial information is positively related to the quality of the board and the quality of the ownership structure. The use of an overall governance index gives more significant results for the three models and affirms the positive relationship between the quality of governance system and the quality of financial reporting.
\end{abstract}

Keywords:financial information, ownership structure, corporate governance, discretionary accruals, board of director

\section{Introduction}

The propagation of crises in recent years has called into question the governance policy practiced by companies internationally. This has prompted regulators to propose new laws of good conduct and financial security offering a series of recommendations perceived as best practices of governance. These reports were considered to be a benchmark in corporate governance. They help companies to reduce mismanagement, to remedy any deficiencies in governance mechanisms to prevent abuse of power and to manage risks. Compliance with these recommendations is the essential basis for evaluating the quality of the governance system, and therefore the protection of the reputation of the company.

In this context, the quality of the corporate governance is a necessary condition to assure and maintain the confidence of stakeholders. In fact, they perceive the company of good governance quality as the less risky it is likely to contribute to the increase in its share price. Codes of conduct attach importance to the financial information quality provided by the firms.

Improving transparency and disclosure can lead to a positive effect on the system of governance. Studies on the relationship between these two variables have attracted the attention of many researchers. But most chooses the analysis of fragmented governance i.e the inclusion of each mechanism apart (size of board of directors, duality, board independency ...). There are few studies that have used systemic analysis based on the index or score governance. Our study consists to choose the overall index of governance and some sub-indices to assess the governance mechanisms. The same research that used the score governance often focuses on the relationship between corporate governance and performance (Bozec and Bozec, 2012 ; Gupta et al, 2009). To our knowledge, there is no study that has tried to detect the presence of a relationship between corporate governance index (systemic approach) and the quality of financial reporting.

To assess the quality of financial reporting, several measures have been proposed. Among which accruals models, models of earnings relevance and methods incorporating qualitative characteristics (Van Beest, Braam and Boelens, 2009).A literature review of these models has been discussed by Casta and Stolowy, (2012), Dechow et al., (2010) and Gaio (2010). For these authors, the quality of financial information can be approximated by the properties of earning. Among the properties, there is the quality of accruals. Healy (1985) defines accruals as the sum of accounting adjustments to the cash flows of the firm permitted by the standards. The discretionary accruals are determined by the difference between total accruals and non discretionary accruals

According Dechow et al, (2010), "non discretionary accruals can detect adjustments that reflect fundamental performance and the discretionary accruals capture distortions caused by application of earnings management or the 
accounting standards". For these authors if non discretionary accruals are modeled properly, in that case the discretionary component represents a distortion that is of lower quality. Francis et al, (2005) documented that earnings quality represents a mainly source of information risk, and proposed an accrual-based metric of earnings quality. Several models of estimation of discretionary accruals are proposed by the literature.

In this study, we use discretionary accruals approximated by the modified Jones model (1995), Kothari et al. (2005) and Raman and Shahrur (2008) as an indicator of the quality of financial reporting.

According to Francis et al. (2005), a high level of abnormal accruals implies low quality of accounting earning and increases the level of risk among investors.

This study will be arranged as follows: firstly we present the literature review on quality of information, the system of governance and the relationship that may exist between them. Secondly, we present the sample, methodology and variables. At last, results analysis will be presented.

\section{Literature review:}

In the following we will see the literature explaining the relationship between the corporate governance system and the quality of financial reporting.

\subsection{Financial information Quality}

Several definitions of the financial information quality were provided by previous studies. This diversity is explained by the presence of different users and concerning different decisions.

However, the definition that seems interest to the different users at the same time and attract the maximum compromise is proposed by Dechow and Dichev (2002). The approach taken by these authors is to assess the quality of financial reporting using the accruals that trace the achievements of cash flows. Indeed, the measurement of the quality of financial information is based on discretionary accruals. The study by Healy (1985) is the first integrated the concept of discretionary accruals in the accounting literature. Subsequently several models have been proposed and developed.

The discretionary accruals are valued using an estimation model (Jones, 1991; Dechow, Sloan and Sweeney, 1995, Kothari et al, 2005; Shahrur and Raman, 2008). According to Francis, et al. (2005), a higher level of discretionary accruals report low profits and a higher information risk to investors (Ashbaugh, Collins, LaFond, 2004).

Measuring the quality of financial reporting adopted by Dechow and Dichev (2002) is a measure that interested in general all users of financial information (investors, creditors, financial analysts) and in particular creditors. The quality of accruals can be a measure that captures the signals of earnings $(\mathrm{Ng}, 2011)$.

The presence of a part of a negative relationship between the quality of disclosure of information and the level of information asymmetry and the existence of positive correlation between information asymmetry and earning management perspective demonstrate the opportunistic practice by management (Lobo and Zhou , 2001). In that case earning management by director accomplishes two goals: to convince investors and maximize their own interests and the disclosure some information. This study advocates the use of accruals as a method of approximation of the quality of information received by investors. Earnings management can act negatively the quality of financial information by reducing its usefulness for decision making (Van Tendeloo and Vanstraelen, 2005). There are several advantages of the use of discretionary accruals. They can be calculated by using accounting information found in the financial statement.

The discretionary accruals add information to that available in the operating cash flow and in non discretionary accruals. Discretion may be considered as a way for managers to demonstrate to the shareholders their expectations for the future of firm. Earnings management is considered a signal to the market. Investors take into consideration and estimate more accurately the value of the firm which allows them to have a good portfolio of stock.

The importance of discretionary accruals for investors was explained by Guay, Kothari and Watts (1996) and Subramanyam (1996). The first proved the existence of a positive relationship between discretionary accruals and stock prices. The second showed that discretionary accruals have informative value. Indeed, discretionary accruals are used by managers to convey news about future profitability of the company. The positive correlation between market capitalization and amount manipulated shows that earning management transmits information on the value of the firm.

\subsection{Corporate governance system}

Previous empirical literature on corporate governance has assumed independence between the different control mechanisms. Most studies simply examine the correlation between a subset of mechanisms, usually one or two attributes 
of governance and the quality of financial information as such, Demsetz and Lehn (1985) ; Hermalin and Weisbach (1991) ; Yermack (1996) and Haniffa (2002).

However, it must be noted that many authors are criticizing this approach, they consider very limited, because the evaluation of corporate governance by a single dimension may not capture the effect of global governance (Boehren and Oedegaard, 2003; Bauer et al., 2008; Bhagat et al., 2008). These authors argue that firms have a variety of internal and external mechanisms, linked together by the effects of substitutability or complementarity (Charreaux , 1996).

Therefore, it would be more appropriate in this context to use a systemic approach, which relies on the examination at the same time several mechanisms. Each of these mechanisms has an impact on the overall efficiency control (Rediker and Seth, 1995 and Agrawal and Knoeber, 1996). However, there is no consensus on the inclusion of the governance index. Some authors have criticized this approach. (Bozec and Bozec (2012), Bebchuck and Hamdani, 2009).

There are no good measures of the quality of governance since governance is based on the context and characteristics specific to the company. The search for global standards of corporate governance can be considered difficult to achieve (Bozec and Bozec, 2012).

Charreaux(1996), and Ward et al, (2009) reported that there may be a relationship of complementarity or substitutability between governance mechanisms. The first point of view supports the substitutability of control mechanisms Whereas the mechanisms are antagonistic and take turns in time. For cons, the second view affirms their complementarity (they coexist and develop some synergy). The concept of substitutability monitoring systems and incentive to control agency problems has attracted the attention of several researchers (Rediker and Seth, 1995; Tosi, Katz, and Gomez- Mejia, 1997; ward et al, 2009)).

Two mechanisms appear complementary when the strengthening of constraint exerted by one of the mechanisms leads to an increase that associated with another mechanism (Milgrom and Roberts, 1992). By example, the presence of outside directors on the board increases the probability of a successful hostile takeover, in which case the board of directors and takeovers represent complementary mechanisms.

In our present study, we will rely on the assumption of complementary mechanisms to assess the effectiveness of the governance system. This can be explained by two reasons: first, complementarity is a necessary condition to qualify good governance. Then, potential shareholders and the market in general, reflect the efficiency of the whole mechanism and not a single attribute at the time of their assessment of the quality of governance.

Indeed, the efficiency and the quality of the governance system are seen as a guarantee of wealth creation for the various stakeholders (Charreaux, 1996).

As for Hill and Jones (1992), they consider that effective corporate governance system is characterized by its ability to reduce the agency costs of a company.

The issue of measuring the quality of governance system has attracted the attention of many researchers. A consensus seems to be established on the importance of building an overall index of governance that seeks to capture in a single measure the simultaneous adoption of multiple dimensions of governance (Brown and Caylor, 2006). Overall governance index is used to evaluate the quality of governance (Black et al., 2006).

The idea behind the creation of this index is to capture the multiple dimensionality of governance and also give an idea of the level of corporate compliance expectations defined by the codes of good conduct.

Thus, the index as a reference measurement is intended to provide an easily comparable characteristic of the company in respect of governance. It thus helps shareholders, managers and other stakeholders to assess objectively the situation and development of the company in relation to others.

Empirical studies on the quality of governance are classified into two categories: First, studies in which the authors construct themselves, an overall score of governance (Gompers et al, 2003 in the United States; Drobetz et al, 2004 in Germany and Da Silveria and Barros, 2007 in Brazil, Black, Jang and Kim (2005) for Korean companies). Then, those relating to indices produced by specialized rating agencies (Black, 2001; Bauer et al., 2004; Black, Love and Rachivsky, 2006; Bauer et al., 2008). By example, Bauer et al (2008) used the data provided by Governance Metrics International (GMI).

For our study we will try to construct a governance index based on previous studies. This index is the sum of three sub-indices on the quality of the board of directors, ownership structure and audit quality

\subsection{Relationship between disclosure and governance system.}

At this section, we will be interested in the relationship including the quality of the information disclosed and the corporate 
governance system represented by the characteristics of the board, the effectiveness of control system and ownership structure. These mechanisms whose effectiveness are reflected by a good governance system and can influence positively the quality and the level of the information disclosed.

According to the agency theory good governance allows the reduction of conflicts and agency costs, the alignment of interests and therefore the limitation, otherwise the absence of earnings management. It considers that the separation of management and control decisions reduces agency costs. According to the theory of signals, good governance can be a signal indicating the absence of a manipulation of earning by the company. This indicates a disclosure of financial information with higher quality. In fact, this quality of governance depends largely on the information system of the company. Financial information must be reliable and able to provide excellent signal quality of corporate governance system. This signal should be credible, reliable and costly for the company and would be ultimately a mechanism to reduce asymmetric information existing on the market.

From these explanations previously cited, we propose the following hypothesis:

$\mathrm{H}_{1}$ : The presence of a positive impact of good governance on the quality of financial reporting.

\subsubsection{Characteristics of the Board}

According to the agency theory the characteristics of the board can influence the quality and the level of financial information disclosed by firms. Several theoretical and empirical studies have addressed this issue such as the study of Jensen (1993), Healy and Palepu, (2001), Ho and Wong, (2001), Chtourou, Bedard and Courteau 2001 Bujaki and McConomy, (2002); Hanifa and Cook (2002) Clarkson et al., (2003); Gul and Leung, (2004); Barako et al (2006) Cheung (2010).

Among these features, we have: The size of the Board; presence of independent directors, the dual function of Chief Executive Officer (CEO) and Chairman of the Board; and number of board meeting.

A large boards may contain mechanisms for entrenchment (Yermack (1996), Pichard-Stamford (1998) and Godard (2001) Bradbury et al. (2004)). Indeed, a large board has a negative impact on its performance. It increases the problems of communication and coordination. A large board declines the ability of directors to oversee management.

The presence of independents directors can enhance the board's ability to reduce agency conflicts between managers and shareholders, and encourage companies to disclosure voluntarily good financial information in the financial reporting (Chen and Jaggi, 2000; Barako et al, 2006). Frequency of meetings allows board members to monitor and assist managers in the production of information (Xie et al, 2003). Through these studies we can formulate our hypothesis as follows:

$\mathrm{H}_{2}$ : the relationship between information quality and the characteristics of the board is positive

\subsubsection{Audit quality}

According to the guidelines of governance, audit quality is ensured by the existence of an audit committee and an auditor belonging to big4. This committee must have several characteristics such as independence of its members, meets with the external auditor in the absence of leadership. Regarding the quality of the audit committee, Abbott et al. (2001) argue that the presence of members of the audit committee with a lack of experience and expertise creates a high probability of earnings management and fraud. Xie et al. (2003) argue that firms disclosing financial information with higher quality have audit committee members with financial expertise. Expertise of members is an essential condition for the audit committee to accomplish properly its oversight responsibility and effective control and therefore guarantee the reliability of financial reporting (Bédard et al, 2004). The audit committee has as function to ensure a higher level of financial accounting quality and a good control system (Collier, 1993). To ensure the reliability and relevance of accounting information disclosed the Board delegates this task to the audit committee (DeZoort, 1997).

Audit quality also depends on the size of the audit firm measured by the four large auditors in the world (Deloitte Touche Tohmatsu, PricewaterhouseCoopers, Ernst \& Young and KPMG). Through theory, the size of companies is a proxy for audit quality. These firms are independent because they jeopardize their reputation. The big four offer good control and ensure excellent quality information respecting the accounting standards. For Leung, Morris and Gray (2005), the presence of Big4 signal the quality of financial information disclosed by firms and the integrity of financial information.

Based on these arguments, our hypothesis is as follows:

$\mathrm{H}_{3}$ : the relationship between financial information quality and the quality of audit is positive 


\subsubsection{Ownership structure}

According the recommendations of the laws of governance, ownership structure should be dispersed, there was no a family control or a majority shareholder, characterized by the presence of institutional investors or employees shareholding. Through the literature, some researchers have examined the impact of some of these variables on the quality of financial reporting. For example in the presence of family ownership, the level of information disclosed is low. Often, Owners are part of the managerial team. They have access to information. They do not dispose to disclose information to the public. For cons, the presence of institutional investors improves the quality of financial information. They are considered as effective control mechanism. By their behaviors, they provide a good quality of information disclosed. Among authors whose have investigated this issue empirically, we can cited Chau and Gray (2002), Ho and Wong (2001) ; Haniffa and Cooke (2002).

From the explanations we provided previously, we can propose the following hypothesis:

$\mathrm{H}_{4}$ : The audit quality has a positive effect on the quality of financial information

\section{The presentation of data and variable}

\subsection{The presentation of the sample and data}

Firms included in the sample are composed by non-financial French companies listed in SBF250 index for a period of 5 years from 2004 to 2008. The financial and accounting data and the variables related to governance are collected manually via the documents published by companies available to the authority of the financial market. After the removal of missing data our sample includes 101 companies over 5 years is 505 observations. The sample of companies selected is divided into three sectors, namely manufacturing, services and communication.

Table 1. Presentation of the sample

\begin{tabular}{|l|c|}
\hline & Number of firms \\
\hline Companies listed on the SBF 250 & 250 \\
\hline Financial institutions (banks and insurance) & 46 \\
\hline Missing reports for the entire period & 35 \\
\hline Unlisted companies across the period & 14 \\
\hline Missing data & 55 \\
\hline Total & 101 \\
\hline
\end{tabular}

\subsection{The presentation of variables}

\subsubsection{The measures of the quality of the information}

Quality of financial information can be approximated by the discretionary accruals. Several authors have opted for this choice as Francis et al, (2008).

The abnormal accruals are determined by the difference between total accruals and non discretionary accruals estimated using a model proposed by the literature as the model used by Jones (1991), Dechow et al. (1995), Dechow (2002), Kothari and al (2005) and Raman and Shahrur (2008).

In this study, we approximated the accruals for the following three models:

- Dechow et al. (1995)

- Kothari et al (2005)

- Raman and Shahrur (2008).

For the first model the total accruals are calculated as follows:

$$
\frac{\operatorname{TAC}_{i, \mathrm{t}}}{\operatorname{ASSETS}_{\mathrm{i}, \mathrm{t}-1}}=\alpha_{1}\left(1 / \operatorname{ASSETS}_{\mathrm{i}, \mathrm{t}-1}\right)+\frac{\alpha_{2}\left(\Delta \operatorname{SALES}_{\mathrm{i}, \mathrm{t}}-\Delta \mathrm{AR}_{\mathrm{i}, \mathrm{t}}\right)}{\operatorname{ASSETS}_{\mathrm{i}, \mathrm{t}-1}}+\alpha_{3}\left(\frac{\operatorname{PPE}_{\mathrm{i}, \mathrm{t}}}{\operatorname{ASSETS}_{\mathrm{i}, \mathrm{t}-1}}\right)+\mathrm{v}_{\mathrm{i}, \mathrm{t}}
$$


For the second model Kothari et al (2005) added the return on assets. According to this model accruals are represented by the following equation:

$$
\frac{\operatorname{TAC}_{i, \mathrm{t}}}{\operatorname{ASSETS}_{\mathrm{i}, \mathrm{t}-1}}=\alpha_{1}\left(1 / \operatorname{ASSETS}_{\mathrm{i}, \mathrm{t}-1}\right)+\frac{\alpha_{2}\left(\Delta \operatorname{SALES}_{\mathrm{i}, \mathrm{t}}-\Delta \mathrm{AR}_{\mathrm{i}, \mathrm{t}}\right)}{\operatorname{ASSETS}_{\mathrm{i}, \mathrm{t}-1}}+\alpha_{3}\left(\frac{\operatorname{PPE}_{\mathrm{i}, \mathrm{t}}}{\operatorname{ASSETS}_{\mathrm{i}, \mathrm{t}-1}}\right)+\alpha_{4} \operatorname{ROA}_{\mathrm{i}, \mathrm{t}}+\mathrm{v}_{\mathrm{i}, \mathrm{t}}
$$

The final model includes the market to book ratio as a predictor of abnormal accruals.

$$
\frac{\operatorname{TAC}_{i, t}}{\operatorname{ASSETS}_{i, t-1}}=\alpha_{1}\left(1 / \operatorname{ASSETS}_{i, t-1}\right)+\frac{\alpha_{2}\left(\Delta \operatorname{SALES}_{i, t}-\Delta \operatorname{AR}_{i, t}\right)}{\operatorname{ASSETS}_{i, t-1}}+\alpha_{3}\left(\frac{\operatorname{PPE}_{i, t}}{\operatorname{ASSETS}_{i, t-1}}\right)+\alpha_{4} \operatorname{ROA}_{i, t}+\alpha_{5} \operatorname{BM}_{i, t}+v_{i, t}
$$

$\mathrm{TAC}_{\text {it }}$ Total accruals of firm i in year $\mathrm{t}$;

ASSETS $_{\mathrm{i}, \mathrm{t}-1}$ : Total assets of firm i in year $\mathrm{t}-1$;

$\triangle$ SALES $_{i, t}:$ Variation in sales of firm $\mathrm{i}$ in year $\mathrm{t}$;

$\mathrm{PPE}_{\mathrm{i}, \mathrm{t}}:$ Property, plant and equipment of firm $\mathrm{i}$ in year $\mathrm{t}$;

$\mathrm{ROA}_{\mathrm{i}, \mathrm{t}}$ : Return on assets of firm $\mathrm{i}$ in year $\mathrm{t}$;

$\mathrm{BM}_{\mathrm{i}, \mathrm{t}}$ : Book to market of firm $\mathrm{i}$ in year $\mathrm{t}$.

In this study, we calculated the total accruals as the difference between net income and operating cash flow.

The estimation of the above equation allows us to extract the coefficients of the variables that will be used to calculate the non discretionary accruals. By taking the difference between total accruals and discretionary accruals we can determine discretionary accruals.

\subsubsection{Governance system}

We have built three sub-indices of corporate governance from literature review that is an index on the board of director's characteristics, on the ownership structure index and an index for audit quality. This grouping identifies the relationship between the quality of financial information and some indicators of governance. Gupta et al. (2009) and Kolsi et al., (2011) used a governance index composed of four sub-indices made by 'the globe and mail. The four sub-indices are: composition of the board of directors, ownership and compensation, shareholder rights and disclosure.

We used 31 items to construct the index on the characteristics of the board, among them we can mention: The number of directors on the board of directors is between 5 and 12; The Board of Directors is composed of at least $50 \%$ independent directors; The separation between the functions of Chairman of the Board of Directors and the CEO of company; Meetings of the Board are held at least once per quarter; At least $80 \%$ of the directors are present at meetings; The average duration of meetings of the Board exceeds 2 hours; The mandate of a director shall not exceed 4 years; The presence of employee on the Board of Directors; The presence of institutional investors on the board; The reelection of the Chairman; The re-election of members of board; The existence of a nominating, remuneration, and governance committees.

The index for the quality of the ownership structure is consisted by 16 items. By examples:

The first one shareholder holds more than $10 \%$ of equity; the existence of information on shareholding; the major shareholder is not a family; There are no shareholders' agreements.

The principle one vote for one share is respected; the public holds more than $50 \%$; the existence of institutional investors; the institutional investor holds more than $10 \%$ of equity; the existence of foreign institutional investors; the existence of employee shareholding ; The managerial ownership is between $5 \%$ and $25 \%$; the existence of State shareholding.

Finally, the index on the quality of audit and control system includes 17 items among which we can mention: The external auditor belongs to the Big 4; the term of agreement with the company does not exceed 6 years; The existence of a double commission; the existence of statutory auditors' report on the consolidated accounts; the existence of statutory auditors' report on internal control; the existence of an audit committee; independent directors represent at least $2 / 3$ of the members of the audit committee; the number of meeting is superior to 4 per year; The existence of an expert 
in accounting and financial management; the audit committee shall issue a report on its operating activities and procedures for the board of directors.

These three indices i.e. the quality of the board of directors, ownership structure index and the audit quality index are determined as follows:

$$
I_{Q} \text { of firm } j=\left(\sum_{i=1}^{n} \frac{X_{i}}{n}\right) j
$$

$\mathrm{n}$ : is the number of items per index that is 31,17 and 16 respectively for the quality of the board of directors, the quality of audit and ownership structure.

$$
X_{i}=\left\{\begin{array}{l}
1 \text { if the company has proclaimed quality by item } \mathrm{i} \\
0 \text { if not }
\end{array}\right.
$$

\subsubsection{The control variables}

Control variables used are: leverage, performance: status listing and, industry.

We approximated leverage by the ratio (total debt / total assets) among the authors who have used this measure, we can cite Khanna, Palepu and Srinivasan 2004, Leventis and Weetman 2004, Barako et al, 2006; Hassan, Giorgioni and Romilly (2006), Aksu and Kosedag (2006), Ho and Taylor (2007) Jiang et al. (2008).

For the profitability, the researchers used several proxies among them we can mention: ROA, ROE, Tobin's $Q$, operating margin, net profit margin, the ratio Net profit / turnover ratio Sales of Business / book value of equity. About our study we will approximate the performance expected by the market as the study of Khanna, Palepu and Srinivasan (2004) measured by Tobin's Q. This variable indicates the presence of growth opportunities for firms. To attract more investors the company should disclose more information.

Tobin's $Q=$ (market capitalization + market value of debt) /Replacement cost of assets

We approximated Status of listing by a binary variable. We give the value 1 if the firm has a dual listing, and 0 if not. Several researchers used this variable such as Wallace et al. (1994), Hossain et al. (1994), Leventis and Weetman (2004), Arcay and Vazquez (2005).

Our sample is decomposed into three sectors (manufacturing, services and communication). On our model, we have three binary variables. If the company (i) belongs to the sector (j), then assigns the value 1 and 0 if not. With $i=$ from 1 to 101 and $j=1,2,3$

We seek any sector disclosure financial information quality. This variable is used by Watson et al., (2002), Archambault and Archambault (2003), Hanifa and Rashid (2005), Hassan, Giorgioni and Romilly (2006) and Jiang et al, (2008).

\subsection{Presentation of model}

In this study we try to detect the relationship between the quality of financial reporting and governance system. It is for this reason that we have built governance sub-indices and a global index that consists to regroup the three sub-indices into a single index measuring the quality of the governance system (score-gov). Several authors have opted for this approach as Black, Jang and Kim (2006) Jiang et al (2008), Chang and Sun (2008), Kolsi and Ghorbel (2011). For example, Black, Jang and Kim (2006) built themselves a governance index for a sample of 515 Korean firms to seek the relationship between corporate governance and performance. As Jiang et al (2008), their governance index includes both internal and external governance mechanisms. It includes 51 factors covering eight categories, among which we can cite the audit, the Board of Directors, the level of education of the manager, the remuneration of executive directors and the ownership structure.

The pioneering studies have used only one or a few variables on ownership structure or composition of the Board of Directors.

Some authors have criticized this approach, which they consider very limited, because the evaluation of corporate governance by a single dimension may not capture the overall effect of governance on some phenomena such as the quality of financial information or performance (Boehren and Oedegaard, 2003; Bauer et al, 2008, and Bhagat et al, 
2008). These authors argue that companies have a variety of internal and external mechanisms, linked together by the substitutability or complementarity effects (Charreaux, 1996).

It is very useful in this case to opt for a systemic approach, which focuses on the examination at the same time, several mechanisms, since each of these mechanisms has an impact on the overall efficiency of the control (Rediker and Seth, 1995 and Agrawal and Knoeber, 1996). We will rely on the assumption of complementary mechanisms to assess the effectiveness of the governance system.

The use of a global governance index and sub-indices to approximate the quality of governance and 3 measures of discretionary accruals to approximate the quality of the financial information gives us 6 equations to estimate:

Equation 1

$$
\operatorname{DACC}_{1 \mathrm{i}, \mathrm{t}}=\beta_{0}+\beta_{1} L E V_{i, t}+\beta_{2} \mathrm{PRO}_{\mathrm{i}, \mathrm{t}}+\beta_{3} B Q_{\mathrm{i}, \mathrm{t}}+\beta_{4} \mathrm{AQ}_{\mathrm{i}, \mathrm{t}}+\beta_{5} \mathrm{O} Q_{\mathrm{i}, \mathrm{t}}+\beta_{6} \mathrm{ML}_{\mathrm{i}, \mathrm{t}}+\beta_{7} I N D_{\mathrm{i}, \mathrm{t}}+\varepsilon_{\mathrm{i}, \mathrm{t}}
$$

Equation 2

$$
\text { DACC2 } i, t=\beta_{0}+\beta_{1} L E V_{i, t}+\beta_{2} P R O_{i, t}+\beta_{3} B Q_{i, t}+\beta_{4} A Q_{i, t}+\beta_{5} O Q_{i, t}+\beta_{6} M_{i, t}+\beta_{7} I N D_{i, t}+\varepsilon_{i, t}
$$

Equation 3

$$
\operatorname{DACC}_{i, t}=\beta_{0}+\beta_{1} L E V_{i, t}+\beta_{2} P R O_{i, t}+\beta_{3} B Q_{i, t}+\beta_{4} A Q_{i, t}+\beta_{5} O Q_{i, t}+\beta_{6} M_{i, t}+\beta_{7} I N D_{i, t}+\varepsilon_{i, t}
$$

Equation 4

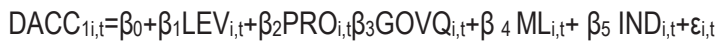

Equation 5

$$
\operatorname{DACC}_{i, t}=\beta_{0}+\beta_{1} L E V_{i, t}+\beta_{2} P R O_{i, t}+\beta_{3} G O V Q_{i, t}+\beta_{4} M L_{i, t}+\beta_{5} I N D_{i, t}+\varepsilon_{i, t}
$$

Equation 6

$$
\text { DACC } 3_{i, t}=\beta_{0}+\beta_{1} L E V_{i, t}+\beta_{2} P R O_{i, t}+\beta_{3} G O V Q_{i, t}+\beta_{4} M_{i, t}+\beta_{5} I N D_{i, t}+\varepsilon_{i, t}
$$

DACC1, DACC2 and DACC3: discretionary accruals estimated respectively by the Dechow et al,(1995), Kothari et al,(2005) and Raman and Sharur(2008);

LEV : leverage

PRO: The Profitability (Qtobin) ;

$B Q$ : board quality

$A Q$ : Audit quality ;

OQ: ownership structure quality;

GOVQ: governance quality;

ML: multiple listing;

IND: industry

\section{Analysis and interpretation of results}

\subsection{The descriptive analysis}

The correlation between two variables is detected by the Pearson correlation matrix. This test shows the presence of bivariate correlation greater than 0.5 between audit quality and the board. So there is a strong correlation between industry and other sectors namely that of communication and services. By the test of multicollinearity, we will know if it is possible or not to reinstate them together in a single equation. We have not identified any indicator of tolerance of a variable lower limit of 0.25 . In addition to the variables used all VIF values are identified below the treeline fixed by Groebner et al, (2005) that is 5. 
Table 2. Pearson correlation matrix

\begin{tabular}{|l|l|l|l|l|l|l|l|}
\hline & LEV & POR & BQ & AQ & OQ & GovQ & ML \\
\hline LEV & 1.0000 & & & & & & \\
\hline POR & -0.2117 & 1.0000 & & & & & \\
\hline BQ & -0.0511 & -0.1517 & 1.0000 & & & & \\
\hline AQ & 0.0188 & -0.1534 & 0.6640 & 1.0000 & & & \\
\hline OQ & -0.0671 & 0.0031 & 0.1562 & 0.1157 & 1.0000 & & \\
\hline GovQ & -0.0421 & -0.1440 & 0.8573 & 0.8310 & 0.5123 & 1.000 & \\
\hline ML & 0.1007 & 0.0620 & 0.0736 & 0.1157 & 0.0323 & 0.1018 & 1.000 \\
\hline
\end{tabular}

LEV : leverage PRO: The Profitability (Qtobin) ; BQ: board of directors quality $A Q$ : Audit quality ;OQ: ownership structure quality; GOVQ: governance quality; ML: multiple listing.

\subsection{The multivariate analysis}

\subsubsection{Use of sub-indices of governance}

The use of sub-indices $B Q, O Q$ and $A Q$ representing the characteristics of the board of directors, ownership structure and audit quality as determinants of the quality of the financial information give the following result: the quality of the board affects negatively the manipulation of information by management and affects positively the quality of the information disclosed. A firm, that disclosure information with higher quality has many characteristics. Among them, the number of directors on board, respecting the threshold set by Jensen (1993) and Campos (2002) is between 5 and 12 members. It has more than two thirds independent directors, the members attend to meetings regularly and there are separation of functions between CEO and chairman. The relationship between the quality of the structure ownership and discretionary accruals is negative only for the model of Dechow et al, (1995). The result shows that the ownership structure positively influences the quality of financial reporting. Indeed, the absence of majority family ownership, the dispersion of ownership, the presence of employee shareholding, and the presence of institutional investors with a share superior to $10 \%$ are the characteristics of a good ownership structure. Some empirical studies demonstrate the presence of a relationship between these mechanisms and the quality of financial information. For example, institutional investors have access to information. They participate in the production of information. They present effective mechanisms of control of the Board.

For the three equation, control variables are all expected signs and significant. We find that the quality of information is better for a company with a high leverage. This result is significant at the $5 \%$ level for the modified Jones model (1995), and Raman and Shahrur, (2008) and 10\% for the model of Kothari et al. (2005). The same result is obtained by Becker et al, (1998). The positive relationship is justified by the reduction in agency costs and facilitates the risk assessment by creditors (Botosan 1997, Botosan and Plumlee 2000). Creditors need more information to ensure their funds. The relationship between the quality of financial reporting and profitability is positive. The company with growth opportunities and with good profitability, disclose information of good quality. This ensures investors on the prospects of the company. We also found a company listed on several stock markets disclosure more information with higher quality than a company whose securities are traded on a single stock exchange market. Companies listed on several stock markets often follow international accounting standards which the level of information required is very important. 
Table 3. The result of estimating the relationship between the quality of financial reporting and governance quality (sub-indices)

\begin{tabular}{|c|c|c|c|c|c|c|}
\hline Variables & coefficient & t-student & Equation 2 & t-student & Equation 3 & $t$-studen \\
\hline LEV & $-.025565^{* *}$ & -2.20 & $-.0211408^{*}$ & -5.50 & $-.0223725^{* *}$ & -2.01 \\
\hline PRO & $-.015022^{* * *}$ & -5.46 & $-.0152997^{* * *}$ & -5.50 & $-.0137561^{* * * t}$ & -4.96 \\
\hline$B Q$ & $-.0509714^{* * *}$ & -3.80 & $-.0509989^{* * *}$ & -3.98 & $-.0507779^{* * *}$ & -4.12 \\
\hline$O Q$ & $-.0197599^{*}$ & -1.65 & -.0157353 & -1.35 & -.0137021 & -1.20 \\
\hline$A Q$ & -.0139825 & -0.88 & -.0175293 & -1.15 & -0.0173843 & -1.19 \\
\hline $\mathrm{ML}$ & $-0.012848^{*+* x}$ & -4.14 & $-0.011543^{* * *+}$ & -3.91 & $-0.11191^{* * *}$ & -3.91 \\
\hline MAN & $0.0080413^{* *}$ & 2.59 & $.0081743^{* * *}$ & 3.44 & $.0085848^{* * *}$ & 2.96 \\
\hline Constante & $.0440592^{* * *+}$ & 3.78 & $.0393833^{*+* t}$ & 3.44 & $.0323352^{*+*}$ & 2.85 \\
\hline Wald chi2(7) & $77.12^{*+*}$ & & $79.00^{*+* *+}$ & & $76.21^{\text {t*t* }}$ & \\
\hline
\end{tabular}

LEV : leverage PRO: The Profitability (Qtobin) ; BQ: board quality AQ: Audit quality ;OQ: ownership structure quality; ML: multiple listing; MAN: manufacturing industry. $\left(^{*}\right),\left(^{* *}\right)$ and $\left(^{* *}\right)$ respectively significant at a level of $10 \%, 5 \%$ and $1 \%$.

\subsubsection{Using the governance index}

Recent research studies are moving more towards systemic analysis and qualitative corporate governance and abandon, therefore, the fragmented approach which focuses solely on the impact of some control mechanisms, usually taken one by one. These studies seek to build a corporate governance index composed by several items relating to audit system, board of directors, ownership structure, executive compensation and market discipline (Gomper et al, 2003; Bebchuk, Cohen and Ferrell, 2005; Brown and Caylor, 2006 and Jiang et al, 2008).

Indeed, the governance system consists by a set of control mechanisms interconnected and can be complementary.

To detect the relationship between the quality of financial reporting and the effectiveness of governance mechanisms, we proposed a governance index that includes all three sub-indices

(board of directors, audit and ownership structure) based on the studies of Brown and Caylor (2006) and Jiang et al. (2008).

The estimation in the presence of governance quality index gives more significant results for the different estimation models. The significativity of variables is improved by the introduction of this index. The quality of financial information approximated by discretionary accruals indicates the presence of a positive relationship with leverage. A company with higher leverage disclosure information with higher quality to avoid conflicts with creditors and there is also less earnings management. Similarly, we detected a positive relationship with performance. In fact, a profitable firm discloses more information to indicate the credibility of its reported earnings, to increase its reputation and to avoid undervaluation of its shares.

Table 4. The result of estimating the relationship between the quality of financial reporting and governance quality (overall index)

\begin{tabular}{|c|c|c|c|c|c|c|}
\hline Variables & Equation 4 & t-student & Equation 5 & t-student & Equation 6 & t-student \\
\hline LEV & $-0.0232024^{* *}$ & -2.04 & $-0.019485^{*}$ & -1.79 & $-0.0215648^{* *}$ & -1.99 \\
\hline PRO & $-0.015076^{\text {tat }}$ & -5.50 & $-0.0153792^{2 * *+}$ & -5.58 & $-0.013881^{\text {twot }}$ & -5.03 \\
\hline GOVQ & $-0.104490^{*+*}$ & -6.30 & $-0.0997983^{*+* x}$ & -6.71 & $-0.098178^{*+*+*}$ & -6.66 \\
\hline$M L$ & $-0.013252^{*+*}$ & -4.37 & $-0.0120235^{5+* t}$ & -4.19 & $-0.011428^{*+* t}$ & -4.03 \\
\hline MAN & $0.0058615^{* *}$ & 2.54 & $0.0081039^{* * *}$ & 2.77 & $0.0085675^{* * *}$ & 2.97 \\
\hline Constante & $0.053434^{*+* t}$ & 5.20 & $0.0500752^{* * *}$ & 5.02 & $0.0434644^{*+* x}$ & 4.37 \\
\hline Wald chi2(5) & 74.91 & & 77.63 & & 72.74 & \\
\hline
\end{tabular}

LEV : leverage; PRO: The Profitability (Qtobin); GOVQ: governance quality; ML: multiple listing; MAN : manufacturing industry. $\left.\left(^{*}\right),{ }^{* *}\right)$ and $\left.{ }^{* * *}\right)$ respectively significant at a level of $10 \%, 5 \%$ and $1 \%$. 
For the relationship between the index of governance quality and discretionary accruals, it is negative and significant at the $1 \%$ level. There is few earning management in the presence of good governance. This result is similar to those of Chang and Sun (2008) and Jiang et al (2008).

Using a sample of 1036 firms, Chang and Sun (2008) found a significant negative relationship between discretionary accruals and the quality of corporate governance measured by a score of aggregated governance and consists of five variables. suggesting that the mechanisms of individual corporate governance could gradually complete control of performance management. Same effect is obtained by Jiang et al. (2008) for a sample consists of 1737 nonfinancial firms for a period of three years from 2002 to 2004. Based on the agency theory, we can find an explanation for this relationship. Indeed, the presence of good governance provides for the reduction of agency costs and finds a consensus in the interests of stakeholders (shareholders, creditors, and managers) that leads to the decrease in earnings management.

Better governance also reduces the information asymmetry in the market by issuing a signal indicative of the absence of earnings management. Good governance can establish trust with stakeholders, represented by their assessment of the actual performance of the company and protection of their rights.

\section{Conclusion}

At this study, we tried to find the relationship between the system of corporate governance and the quality of financial information approximated by discretionary accruals measured by three estimation models (Dechow et al, 1995; Kothari et al, 2005 and Raman and Shahrur, 2008).

Governance system is appreciated by a global index and three sub-indices relating to the characteristics of the board, ownership structure and quality control.

The use of systemic analysis often provides more effective results than the fragmented approach, i.e. the integration of certain governance mechanisms such as board size or the presence of independent directors

The results show a positive relationship between the quality of financial information disclosed and the leverage, the performance and the multiple listing whatever the estimation model chosen.

The association involving the ownership structure and the quality of financial information is verified only for the accruals estimation model of Dechow et al, (1995).

The use of an overall governance index as the studies of Black et al, (2006) and Jiang et al, (2008) gives more significant results for the three models and affirms the positive link among the quality of financial reporting and the quality of governance.

Our study has developed the following main contributions: understanding the concept of voluntary disclosure and its relationship with corporate governance. The use of an index of corporate governance quality apprehends an effective control system.

Construction of self governance index can be considered as a limit presented by the problem of subjectivity. So the same weights to the various items is criticized by some researchers, they prefer to assign different values to different items. Others attribute of earning can be used as proxy of the quality of financial reporting. As indicated by Gaio (2010), the quality of financial information is multidimensional. It is also useful to see the economic consequences of the quality of financial reporting.

\section{References}

Agrawal, A \& Knoeber, C.R., (1996). Firm performance and mechanisms to control agency problems between managers and shareholders. Journal of Financial and Quantitative Analysis.31(3). 377-397.

Akhtaruddin J.(2005). Corporate mandatory disclosure practices in Bangladesh. The International Journal of Accounting. 40. $399-422$.

Aksu, M. \&Kösedağ, A. (2006).Transparency and disclosure scores and their determinants in the Istanbul Stock Exchange. Corporate Governance: an International Review. 14(4).277-296.

Archambault, J. \& Archambault, M. (2003). A multinational test of determinants of corporate disclosure. The International Journal of Accounting. 38. 173-194.

Arcay R B\&Vázquez F M, (2005). Corporate characteristics, governance rules and the extent of voluntary disclosure in Spain. Advances in Accounting.21. 299-331.

Barako D.G. Hancock. P.\&lzan H.Y.(2006). Factors Influencing Voluntary Corporate Disclosure by Kenyan Companies. Corporate Governance: An International Review. 14(2 ). 107-125. 
Bauer, R., Frijns, B., Otten, R \& A.Tourani-Rad, A., (2008). The impact of corporate governance on corporate performance: evidence from Japan. Pasific Basic Finance Journal.16.236-251.

Beasley, M.S., (1996).An Empirical Analysis of the Relation between the Board of Director Composition and Financial Statement Fraud. The Accounting Review. 71. 443-465.

Becker, C.L., Defond, M.L., Jiambalvo, J. \& subramanyam, K.R. (1998). The effect of audit quality on earnings management . Contemporary Accounting Research. 15(1). 1-24.

Bhagat, S \& Bolton, B., (2008).Corporate governance and firm performance. Journal of Corporate Finance.14.257-273.

Black, B., Jang, H \&Kim, W., (2006). Does corporate governance predict firms' market values? Evidence from Korea, Journal of Law. Economics, and Organization .22.366-413.

Botosan, C. A. (1997). Disclosure level and the cost of capital. The Accounting Review.72(3).323-349.

Botosan, C. A., \& Plumlee, M. A. (2002). A re-examination of disclosure level and the expected cost of equity capital. Journal of Accounting Research.40(1). 21-40

Bradbury, M. E. (1992). Voluntary disclosure of financial segment data: New Zealand evidence. Accounting and Finance. 32 (1). $15-26$.

Bradbury, M.E., Mark, Y.T \& Tan, S.M. (2004). Board characteristics, audit committee characteristics and abnormal accruals. Accounting Law and Finance.1- 27.

Brown, L.D., \&Caylor M.L. (2006). Corporate governance and firm valuation. Journal of Accounting and Public Policy. 25. 409 434.

Bujaki, M. \& McConomy, B. (2002). Corporate governance: factors influencing voluntary disclosure by publicly traded Canadian firms. Canadian Accounting Perspectives. 1(2).105-139.

Charreaux, G., (1996). Pour une véritable théorie de la latitude managériale et du gouvernement des entreprises. Revue Française de Gestion.50-64.

Chau G. K., \& Gray S. J. (2002). Ownership structure and corporate voluntary disclosure in Hong-Kong and Singapore. The International Journal of Accounting. 37(2). 247-265.

Chang, J-C., \&Sun, H-L. (2008). The Relation Between Earning In formativeness, Earnings Management and Corporate Governance in the Pre-and Post-Sox periods, MidAtlantic Regional Meeting of American Accounting Association.

Cheung, Y.-L., Jiang P., \& Tan W.(2010). A transparency Disclosure Index measuring disclosures:Chinese listed companies. Journal Accounting Public Policy.

Chtourou, M. S, Bédard, J \& Courteau, L (2001). Corporate governance and earnings management. Working paper. Laval University. 1-41.

Clarkson P. M., Ferguson C.,\& Hall J. (2003). Auditor conservatism and voluntary disclosure : evidence from the year 2000 systems issue. Accounting and Finance. 43. 21-40.

Collier P. (1993). Factors Affecting the Formation of Audit Committees in Major UK Listed Companies. Accounting and Business Research. 23 (91). 421-30.

Cooke, T. E. (1989). Voluntary corporate disclosure by Swedish companies. Journal of International Financial Management and Accounting. 1(2). 171-95.

Cooke, T. E. (1991). An assessment of voluntary disclosure in the annual reports of Japanese corporations. The International Journal of Accounting. 26. 174-189.

Cremers, K.J.M \& Nair, V.B, (2005). Governance Mechanisms and equity prices. Journal of Finance.60(6).2859-2894.

Datar , S., Feltham, G. \& Hughes, J. (1991). The role of audits and audit quality in valuing new issues. Journal of Accounting and Economic.14(1). 3-49.

Dechow, P.M. \& I.D. Dichev, (2002). The quality of accruals and earnings: The role of accrual estimation errors. The Accounting Review. 77. 35-59.

Dechow, P., R. Sloan, \& A. Sweeney. (1995). Detecting earnings management. The Accounting Review. 70. $193-225$.

Dechow, Ge, \& Schrand(2010). Understanding earnings quality: A review of the proxies, their determinants and their consequences.Journal of Accounting and Economics. 50(3).344-401.

Demsetz, H \& Lehn, K., (1985). The structure of corporate ownership: causes and consequences. The Journal of Political Economy.93(6).1155-1177.

DeZoot, T., (1997). An Investigation of Audit Committees' Oversight Responsibilities. Abacus. 33(9). 208-227.

Drobetz, W., Schillhofer, A \&Zimmermann, H., (2004). Corporate governance and expected stock returns: evidence from Germany. European Financial Management.10(2).267-293.

Francis J., Nanda D. \& Olsson P.,(2008). Voluntary Disclosure, Earnings Quality, and Cost of Capital . Journal of Accounting Research . 46(1).53-99.

Francis, J. R., Khurana I.K., \& Pereira R.,(2005). Disclosure Incentives and Effects on Cost of Capital Around the World. Accounting Review. 80. 1125-1162.

Forker, J.J (1992). Corporate governance and disclosure quality. Accounting and Business Research. 22(86).111-124. 
Fan J. P. \&Wong T.J. (2005). Do External Auditors Perform a Corporate Governance Role in Emerging Markets? Evidence from East Asia. Journal of Accounting Research. 43( 1 ).

Guay, W.R., S. Kothari \&R.I. Watts (1996). A market based evaluation of discretionary accruals models. Journal of Accounting Research. 34.83-105.

Gul F., \&Leung S.(2004). Board leadership, outside directors' expertise and voluntary corporate disclosures. Journal of Accounting and Public Policy. 23. 351-379.

Gomper's, P., Ishii, J. \& Metrick, A. (2003). Corporate Governance and Equity prices. Quaterly Journal of Economics.118. 107155.

Gaio(2010). The Relative Importance of Firm and Country Characteristics for Earnings Quality around the World. European Accounting Review. 19(4). 693-738.

Hanifa, R. M. \& Cooke, T. E. (2002). Culture, corporate governance and disclosure in Malaysian corporations. Abacus. 38.( 3). 317-349.

Hanifa, M.H., \& Rashid, H. (2005). The determinants of voluntary disclosures in Malaysia: The case of internet financial reporting. UNITAR E-Journal. 2(1). 22-42.

Hassan Omaima A.G., Romilly P. ,\&Gianluigi G.(2006). The extent of financial disclosure and its determinants in an emerging capital market: the case of Egypt. International Journal Accounting, Auditing and Performance Evaluation. 3(1).41-67.

Hermalin, B.E. \& Weisbach, M.S., (1991). The effects of board composition and direct incentives on firm performance. Financial Management.20.101-112.

Hill, C.W \& Jones, T.M., (1992). Stakeholder-Agency theory. Journal of Management Studies.132-154.

Healy, P. M. \& J. M. Wahlen. (1999). A review of the earnings management literature and its implications for standard setting. Accounting Horizons .12. 365-383

Healy, P.M. (1985). The effect of bonus schemes on accounting decisions. Journal of Accounting and Economics. 7.(3). 85-107.

Healy, P. M. \& Palepu, K. G. (2001). Information asymmetry, corporate disclosure, and the capital markets: A review of the empirical disclosure literature. Journal of Accounting and Economics. 31. 405-440.

Hossain, M., Tan, L. M., \& Adams, M. (1994). Voluntary disclosure in an emerging capital market: Some empirical evidence from companies listed on the Kuala Lumpur Stock Exchange. The International Journal of Accounting. 29.334-351.

Ho L. \&Taylor M.E. (2007). An Empirical Analysis of Triple Bottom-Line Reporting and its Determinants: Evidence from the United States and Japan. Journal of International Financial Management \& Accounting. 18. (2). 123-150.

Ho, S. S. M., \& Wong, K. S. (2001). A study of the relationship between corporate governance structures and the extent of voluntary disclosure. Journal of International Accounting, Auditing and Taxation. 10. 139-156.

Khanna, Palepu \& Srinivasan (2004). Disclosure Practices of Foreign Companies Interacting with U.S. Markets. Journal of Accounting Research. 42.(2) . 475-508.

Klapper, F.L \& Love, I., (2004). Corporate governance, investor protection, and performance in emerging markets. Journal of Corporate Finance.10.703-728.

Kothari, S.P., Leone A.J \& Wasley C.E. (2005). Performance matched discretionary accrual measures . Journal of Accounting and Economics. 39.163-197.

Jiang W., Lee P. \& Anandarajan, A. (2008). The association between Corporate Governance and Earning Quality: Further evidence using the Gov-Score. Advances in Accounting, incorporating Advances in International Accounting. 24.(2).191201.

Jones, J. (1991). Earnings management during import relief investigation. Journal of Accounting Research .29.193-228.

Jensen, M.C., (1993). The modern industrial revolution exit, and the failure of internal control system . Journal of Finance.48. 831-880.

Leventis S. \& Weetman P. (2004). Timeliness of financial reporting: applicability of disclosure theories in emerging capital market. Accounting and Business Research. 34 (1). 43-56.

Lobo, G.L. \&Jian Zhou. (2001). Disclosure quality and earnings management. Asia-Pacific Journal of Accounting and Economics. 8 (1). 1-20.

Mc Kinnon, J.L., \&Dalimunthe, L. (1993). Voluntary disclosure of segment information by Australian diverisified companies. Accounting and Finance. 33. 33-50.

Meek, G. K., Roberts, C. B., \& Gray, S. J. (1995). Factors influencing voluntary annual report disclosures by U.S., U.K. and Continental European Multinational Corporations. Journal of International Business Studies. 26(3).555-572.

$\mathrm{Ng}$, J.(2011). The effect of information quality on liquidity risk. Journal of Accounting and Economics. 52(3). 126-143.

Prencipe, A. (2004). Proprietary costs and determinants of voluntary segment disclosure: evidence from Italian listed companies. European Accounting Review. 13(2). 319 -340.

Pichard-Stamford J.-P.,(1998). La légitimation du dirigeant par le réseau des administrateurs. Actes des XIVèmes Journées nationales des I.A.E.tome 2. Nantes. 389-407. 
Raffournier, B. (1995). The determinants of voluntary financial disclosure by Swiss listed companies. The European Accounting Review. 4(2). 261-280.

Raman, K. \& H. Shahrur, (2008). Relationship-specific investments and earnings management: Evidence on corporate suppliers and customers, Accounting Review. 83.1041-1081.

Rediker, K.J \& Seth, A., (1995). Boards of directors and substitution effects of alternative governance mechanisms. Strategic Management Journal.16. 85-99.

Subramanyam, K.R. (1996). The pricing of discretionary accruals. Journal of Accounting and Economics. 22. 249-281.

Van Beest F., Braam G.,\& Boelens S. (2009). Quality of Financial Reporting: measuring qualitative characteristics. Nijmegen Center for Economics (NiCE) Working Paper 09-108.

Van Tendeloo \& Vanstraelen(2005). Earnings Management under German GAAP versus IFRS. European Accounting Review.14(1).

Verrecchia, R.E., (2001). Essays on Disclosure. Journal of Accounting and Economics. 32. 97-180.

Wallace RSO, Naser K,\& Mora A (1994). The relationship between the comprehensiveness of corporate annual reports and firm specific characteristics in Spain. Accounting Business Research. 25(97).41-53.

Watson, A., Shrives, P. \& Marston, C. (2002). Voluntary disclosure of accounting ratios in the UK. British Accounting Review.34. 289-313.

Yermack D., (1996). Higher market valuation of companies with a small board of directors. Journal of Financial Economics. 40(2). 185-211. 